\section{Muhammad Fikar}

PNS Kabupaten Gayo Lues, Nangroh Aceh Darussalam

muhammmadfikar225@ymail.com

\section{Dyah Mutiarin}

Dosen Magister Ilmu Pemerintahan Universitas Muhammadiyah Yogyakarta dyahmutiarin@umy.ac.id

http://dx.doi.org/10.18196/

igpp.2014.0018

\section{Tata Kelola Kebijakan Qanun Nomor 13 Tahun 2003 Tentang Maisir (Perjudian) Di Kabupaten Gayo Lues Provinsi Aceh}

\begin{abstract}
The concept of regional autonomy and the views from the historical Aceh considered appropriate to enforce Sharia Law kaffah. Qanun No.13 of 2003 about Maisir (Gambling) is one of the five existing Qanun in the implementation Islamic Sharia in Aceh, with the aim of preventing all forms of implementation and support for implementing gambling, to implement Islamic Sharia there are three institutions that run(1) Department of Islamic Sharia, (2) Satpol PP and WH, (3) Syariah Court. Bu tthe reality is still going on various forms of gambling. The above considerations, there view was conducted in order to see how the Governance Policy Qanun No.13 of 2003 about Maisir (Gambling) in Gayo Lues Regencyof Aceh province and Relationships between Implementing Agencies. The method used in answering the review using qualitative descriptive method to obtain aclear description of the public participation, LSM in the implementation of Qanun No.13 of 2003 and the relationship between the executing agency. Therefore, the technique in collecting the data that used is observation technique which is observe the objects condition in the field, interview the performers who involved in implementing Qanun Nomor 13 in 2013 about Maisir (gambling) in regency of GayoLues with record it in a document.
\end{abstract}

Keywords: Government Policy and The Relation Of Institute.

\begin{abstract}
ABSTRAK
Konsep Otonomi Daerah dan dilihat dari historisnya Aceh dianggap pantas untuk menjalankan syariat Islam secara kaffah. Qanun No.13 Tahun 2003 tentang Maisir (Perjudian) adalah salah satu dari kelima Qanun yang ada dalam pelaksanaan Syariat Islam di Aceh, dengan tujuan untuk mencegah segala bentuk pelaksanaan dan dukungan terhadap pelaksana perjudian, untuk melaksanakan program Syariat Islam itu ada tiga lembaga yang menjalankannya: (1) Dinas Syariat Islam, (2) Satpol PP dan WH, (3) Mahkamah Syariah. Akan tetapi realitasnya masih terjadi berbagai bentuk perjudian. Atas pertimbangan tersebut, maka tinjauan ini dilakukan dalam rangka melihat bagaimana Tata Kelola Kebijakan Qanun Nomor 13 Tahun 2003 Tentang Maisir (Perjudian) Di Kabupaten Gayo Lues Provinsi Aceh dan Hubungan antar Lembaga Pelaksana. Metode yang digunakan dalam menjawab tinjauan tersebut mengunakan metode Deskriptif Kualitatif guna memperoleh gambaran yang jelas mengenai partisipasi masyarakat, LSM dalam pelaksanaan Qanun Nomor 13 tahun 2003 serta hubungan antar lembaga pelaksananya. Sedangkan teknik pengumpulan data yang digunakan adalah teknik observasi yaitu mengamati kondisi obyektif dilapangan, mewawancarai pelaku-pelaku yang terlibat dalam pelaksanaan Qanun Nomor 13 tahun 2003 tentang Maisir (perjudian) di Kabupaten Gayo Lues dengan mendokumentasikannya.

Kata Kunci: Tata Kelola Kebijakan Dan Hubungan Pemerintah.
\end{abstract}




\section{PENDAHULUAN}

Pemerintah Republik Indonesia melalui Undang-Undang seperti Undang-undang Nomor 18 Tahun 2001 tentang Otonomi Khusus Bagi Provinsi Nanggroe Aceh Darussalam yang kemudian menjadi Provinsi NAD, selain memberikan kewenangan menjalankan syariat juga memberikan landasan hukum bagi peradilan syariah di Provinsi NAD. Undang-undang ini juga memuat penegasan bahwa kewenangan menjalankan syariat Islam ini merupakan bagian tidak terpisahkan dari otonomi khusus yang diberikan oleh pemerintah pusat sesuai dengan kebutuhan khusus daerah dan masyarakat di wilayah provinsi ini. Pemberian otonomi khusus kepada Provinsi Nanggroe Aceh Darussalam (NAD), yang di dalamnya termasuk kewenangan penuh menegakkan syariat Islam, merupakan harapan masyarakat Aceh sejak lama. Masyarakat Aceh telah sejak lama dikenal sebagai bumi "serambi Mekah", sebuah penyebutan yang merefleksikan penghayatan dan pengamalan syariat Islam mewarnai setiap sendi kehidupan masyarakat. Kewenangan penegakan syariat Islam yang berpayung hukum pada peraturan perundang-undangan pemerintah pusat ini, kemudian ditindaklanjuti dengan dibentuknya sejumlah peraturan daerah untuk wilayah provinsi yang dikenal dengan qanun. Upaya untuk kepentingan penegakan syariat Islam ini, hingga kini telah dibentuk sejumlah qanun. Khusus untuk kepentingan penegakan hukum pidana Islam (Jinayah), hingga tahun 2013 telah dibentuk lima qanun sebagai sumber hukum materiil. Kelima qanun dimaksud adalah, (1) Qanun Nomor 11 Tahun 2002 tentang pelaksanaan syariat Islam bidang aqidah, ibadah dan syiar Islam; (2) Qanun Nomor 12 tahun 2003 tentang khamar (minuman keras) dan sejenisnya; (3) Qanun Nomor 13 Tahun 2003 tentang Maisir (judi); (4) Qanun Nomor 14 Tahun 2003 tentang Khalwat (mesum); dan (5) Qanun Nomor 7 Tahun 2004 tentang Pengelolaan Zakat. Dari ke lima qanun yang telah penulis sebutkan diatas mulai dari qanun Qanun Nomor 11 Tahun 2002 tentang pelaksanaan 
syariat Islam bidang aqidah, ibadah dan syiar Islam, Qanun Nomor 12 tahun 2003 tentang khamar (minuman keras) dan sejenisnya, Qanun Nomor 13 Tahun 2003 tentang Maisir (judi), Qanun Nomor 14 Tahun 2003 tentang Khalwat (mesum), dan sampai pada Qanun Nomor 7 Tahun 2004 tentang Pengelolaan Zakat, akan tetapi yang menjadi fokus penulis adalah terkait dengan Qanun Nomor 13 Tahun 2003 tentang Maisir (judi) karena jika kita melihat konten yang menjadi larangannya sangat menarik karena di daerah manapun yang berkaitan dengan judi diseluruh daerha di Indonesia pasti dilarang, oleh karena itu penulis ingin melihat sejauh mana pengaruh Implementasi Qanun Nomor 13 Tahun 2003 tentang Maisir (judi) tehadap perjudian di Aceh khususnya di kabupaten Gayo Lues. Adapun tujuan dari Qanun ini adalah untuk memelihara dan melindungi harta benda/kekayaan, mencegah anggota mayarakat melakukan perbuatan yang mengarah kepada maisir, melindungi masyarakat dari pengaruh buruk yang timbul akibat kegiatan dan/atau perbuatan maisir, meningkatkan peran serta masyarakat dalam upaya pencegahan dan pemberantasan perbuatan maisir.

Maisir (Perjudian) adalah kegiatan dan/atau perbuatan dalam bentuk permainan yang bersifat taruhan antara dua pihak atau lebih dimana pihak yang menang mendapatkan bayaran. Bahwa pada hakikatnya maisir (perjudian) adalah bertentangan dengan agama, kesusilaan dan moral Pancasila, serta membahayakan bagi penghidupan dan kehidupan masyarakat, bangsa dan negara (Qanun No.13 Tentang maisir (perjudian) (Pada Bab Penjelasan). Namun melihat kenyataan dewasa ini, perjudian dengan segala macam bentuknya masih banyak dilakukan dalam masyarakat, sedangkan ketentuan dalam Undang-undang Nomor 7 Tahun 1974 tentang Penertiban Perjudian masih memungkinkan legalisasi perjudian oleh pemerintah dengan alasan tertentu dan di tempat tertentu dan tentunya dapat menjerumuskan orang Islam dalam perjudian 
tersebut, hal ini senada dengan tertangkapnya bandar tato gelap (togel) oleh aparat Kepolisian Sektor (Polsek) Kota Blangkejeren, Gayo Lues telah menciduk lima penjudi tato gelap (togel) di dua lokasi secara terpisah, Minggu (14/7), sekira pukul 21.00 WIB hingga pukul 22.00 WIB. Kelima bandar togel dimaksud sempat diamankan di Mapolsek Blangkejeren, untuk proses penyidikan (diakses pada tanggal 5 november 2013: www.gayolues-syariatislam.com). Merebaknya judi tebak angka karena adanya bandar, tukang tulis, tukang jemput rekap dan tukang pasang, tukang mimpi serta adanya beberapa oknum Polri, TNI, oknum aparat penegak hukum lain, oknum PNS, oknum kepala desa serta keterlibatan masyarakat lainnya Tata Kelola kebijakan yang dikeluarkan oleh pemerintah atas Qanun nomor 13 tentang maisir (perjudian) maka pemerintah Aceh membentuk lembaga pelaksana terhadap kebijakan Qanun tersebut. Ada tiga lembaga yang akan mengimplementasikan Qanun nomor 13 tentang maisir (perjudian). Pertama, Makamah Syariah Islam ( MSI). Keputusan Presiden No. 11 Tahun 2003 tentang Mahkamah Syar'iyah di NAD. Berdasarkan Keppres ini, perkara pidana yang diatur di dalam qanun, saat ini menjadi ranah Mahkamah Syariah. Tiga qanun (maisir, khamar, dan khlawath) yang sudah resmi diberlakukan di Aceh, saat ini menjadi kompetensi Mahkamah Syariah untuk mengadilinya. Kedua, Wilayatul Hisbah (WH ) yang sekarang di gambung dengan satuan polisi pamong praja (Satpol PP) adalah lembaga yang bertugas membina, mengawasi dan melakukan advokasi terhadap pelaksanaan amar makruf nahi mungkar. WH dan Satpol PP memiliki struktur sampai ke tingkat gampong (desa). Anggota WH dan Satpol PP disebut sebagai muhtasib. Ketiga, Dinas Syariat Islam (DSI) adalah organisasi eksekutif yang mewakili pemerintah dalam upaya penyelenggara syariat Islam, didalam tubuh lembaga Dinas Syariat Islam terdapat perwakilan polisi umum dan PNS. Ketiga lembaga di tersebut yang telah penulis jabarkan sebelumnya yang akan menjalankan Qanun tersebut, 
melihat dari proporsi kerjanya sebenarnya lembaga-lembaga tersebut sudah cukup baik akan tetapi pada realitasnya masih ada pelanggaran perjudian yang terjadi.

\section{KERANGKA TEORI} KEBIJAKAN

Menurut Andarson (Indiahono, 2009:17) mendefinisikan kebijakan sebagai perilaku dari sejumlah aktor (pejabat, kelompok, instansi pemerintah) atau serangkaian aktor dalam suatu bidang kegiatan tertentu. Pembicaraan tentang kebijakan memang tidak terlepas dari kaitan kepentingan antar kelompok, baik ditingkat pemerintahan maupun masyarakat secara umum.

Analisis kebijakan merupakan kajian yang tidak tertutup pada kajian di sektor publik saja, karena sektor privat pun pada banyak hal memanfaatkan metode-metode analisis kebijakan untuk menyelesaikan masalah-masalah yang dihadapi. Menurut Indiahono, (2009:1-3). Setidaknya ada tiga hal yang menyebabkan analisis kebijakan lebih lazim dikenal pada sektor publik, yaitu:

1. Sektor publik, secara nyata memiliki tingkat kompleksitas yang lebih ketimbang sektor privat. Artinya, sektor publik yang sendiri dari banyak aktor dan kepentingan membutuhkan metode yang lebih lengkap untuk menyelesaikan masalah yang dihadapinya. Pemerintah dengan banyak aktor, kepentingan dan kompleksitas masalah lebih membutuhkan alternatif-alternatif kebijakan untuk lebih memuaskan publik (stakeholder) ketimbang masalahmasalah yang dihadapi oleh privat.

2. Sektor publik memiliki resiko lebih tinggi untuk menghadapi masalah-masalah yang tidak dapat diprediksi. Artinya sektor publik lebih memiliki khas untuk mendapatkan masalah-masalah baru dari kondisi yang tidak dapat diprediksi sebelumnya. Kejadian seperti ini lebih dimiliki oleh sektor publik ketimbang sektor privat. 
3. Sektor publik memiliki ruang linkup masalah yang lebih luas ketimbang sektor privat, artinya pemerintah membuuhkan pertimbangangan-pertimbangan yang lebih memiliki cakupan luas, dan pertimbangan-pertimbangan yang lebih kompleks ketimbang analisis kebijakan yang dimiliki sektor privat.

Menurut Dye (Dunn, 2003:110) ada 3 elemen kebijakan dalam sistem kebijakan yaitu: kebijakan publik, pelaku kebijakan, dan lingkungan kebijakan.

GAMBAR. II.1 MODEL DASAR PROSES KEBIJAKAN

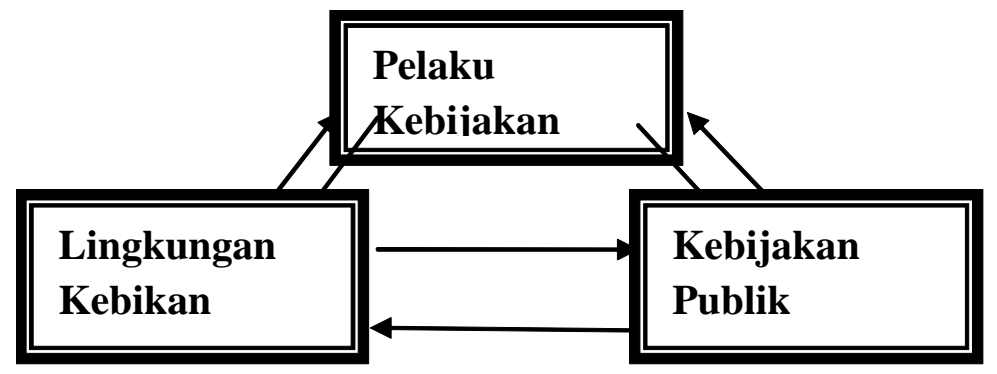

Dari gambar 1, dijelaskan bahwa sistem kebijakan publik mempunyai tiga elemen yang dijelaskan sebagai berikut:

$\varnothing \quad$ Pelaku Kebijakan (Policy Stakeholders):

Pada individu atau kelompok yang mempunyai andil di dalam bidang kebijakan karena mereka mempengaruhi dan dipengaruhi oleh keputusan pemerintah. Pelaku kebijakan misalnya: analisis kebijakan, kelompok warga negara, serikat pekerja, partai, instansi.

$\varnothing \quad$ Lingkungan Kebijakan (Policy Environment):

Konteks khusus dimana kejadian-kejadian di sekeliling khusus kebijakan terjadi, mempengaruhi dan dipengaruhi oleh pembuat kebijakan dan kebijakan publik. Lingkungan kebijakan misalnya: kriminalitas, inflasi, pengangguran, diskriminasi, gelandangan.

$\varnothing \quad$ Kebijakan Publik (Public Policies):

Merupakan rangkaian pilihan yang kurang lebih saling berhubungan (termasuk keputusan-keputusan untuk tidak 
bertindak) yang dibuat oleh badan pejabat pemerintah. Kebijakan publik misalnya mengatur tentang penegakan hukum, ekonomi, kesejahteraan personil, perkotaan. Kebijakan di buat oleh pemerintah untuk mengatasi berbagai problem yang di hadapi, proses pembuatan kebijakan haruslah mengikuti proses analisis kebijakan itu sendiri.

\section{TATA KELOLA KEBIJAKAN}

Menurut Kaufmann (Kuncoro, 2012:78) mendifinisikan Secara luas, tata kelola bermakna tradisi dan lembaga yang menentukan bagaimana kebijakan dilaksanakan dalam sebuah negara. Tata kelola berkaitan dengan strategi, proses, metode, dan mekanisme dalam mengelola negara dan memenuhi permintaan serta kepentingan masyarakat. Sedangkan Weiss (Sumarto, 2004:4) berpandangan lebih jauh menjelaskan tata kelola yang baik berkaitan dengan demokrasi dan pemenuhan hak-hak sipil, dengan transparansi, dengan peraturan hukum, dan dengan pelayanan publik yang efisien. Tata kelola juga melibatkan interaksi institusi publik maupun swasta dengan masyarakat. Kemudian Tong (Kuncoro, 2012:79) mengemukakan bahwa tata kelola yang baik sering dimaknai sebagai pemerintahan yang efektif, yakni merupakan konsep yang multidimensional dan luas.

Bank Dunia ( 1992) mendefinisikan Tata kelola sebagai suatu pelayanan yang efisien, sebuah sistem peradilan yang dapat dipercaya, dan sebuah adminitrasi pemerintahan yang bertanggung jawaban kepada public dan sebagai bentuk pemerintahan yang baik.

Kemudian Bank Dunia juga membuat tiga dimensi tata pemerintahan yang baik sebagai berikut:

1. Bentuk suatu rezim politik (parlementer atau presidensil, militer atau sipil dan ototiter atau demokratis)

2. Proses dimana kewenangan dilaksanakan dalam manajemen sumber daya ekonomi dan sosial suatu Negara; dan 
3. Kapasitas pemerintahan untuk merancang, membentuk, dan melaksanakan kebijakan, dan secara umum kapasitas untuk melaksanakan fungsi-fungsi pemerintahan

Berdasarkan konsep tata kelola pemerintahan di atas, secara operasional, terdapat empat arena tata kelola sebagai berikut:

1. Pemerintah (political-office/pejabat politik);

2. Birokrasi;

3. Masyarakat Sipil;

4. Masyarakat Ekonomi.

Empat arena ini memiliki fungsi dan kinerja yang secara kolektif menentukan kualitas tata kelola di setiap jenjang pemerintahan.

\section{NETWORKING/ JARINGAN}

Networking adalah proses aktif membangun dan mengelola hubungan-hubungan yang yang produktif. Jejaring hubungan yang luas, dan kokoh, baik personal maupun organisasi (Sedarmayati, 2002:34). Didalam jaringan kerja atau networking, mengandung arti sebagai upaya memelihara (nurture, menumbuhkan (cultivate), dan mengintegrasikan (integrate), sehingga dapat dihasilkan kemampuan (capabilitise, talents, saling hubungan (relationship) dan partners. Nilainilai pokok keberhasilan jaringan kerja (networking) adalah individukejujuran, antarpibadi-kepercayaan, manajerial, pemberdayaan, organizational-dan kemitraan.

Wellman mengungkapkan sasaran perhatian utama teori jaringan sebagai berikut: "Analisis jaringan lebih ingin mempelajari keteraturan individu atau kolektivitas berperilaku ketimbang keteraturan keyakinan tentang bagaimana mereka seharusnya berperilaku. Karena itu pakar analisis jaringan mencoba menghindarkan penjelasan normatif dari perilaku sosial. Mereka menolak setiap penjelasan nonstruktural yang memperlakukan proses sosial sama dengan penjumlahan ciri pribadi aktor individual dan norma yang tertanam" (Sedarmayati, 2002:86). 


\section{HUBUNGAN PEMERINTAHAN}

A. INTERAKSI VERTIKAL DALAM PEMERINTAHAN

Interaksi vertikal dalam pemerintahan adalah interaksi antara elemen dalam pemerintahan sifatnya dapat berlansung secara hierarkis oleh pemegang kekuasaan kepada lembaga-lembaga dan wilayah lainnya di mana yang pertama bertindak berdasarkan superior, sementara yang lain subordinat dari dari pusat kekuasaan tersebut. Interaksi dengan model ini merupakan interaksi yang paling klasik dan natural dugunakan oleh manusia. Model ini tampaknya dikonversi dari pengakuan atas kedaulatan Tuhan. Interaksi seperti ini hanya akan efektif apabila kepemimpinan pemerintahan dikelola berdasarkan basis yang diyakini oleh rakyatnya melalui seorang pemimpin yang ideal menurut standar wahyu. Kekuatabn penting akan lahir secara magic melalui standar wahyu yang seterusnya mendorong terbentuk full trust dari rakyat untuk dengan leluasa melakukan apa saja sesuai tuntutan dan kehendak yang maha abstrak. Interaksi dalam hal ini biasanya sangat formil, di mana anggota elemen pemerintahan sangat menjaga nilainilai kepemimpinan sebagai pusat kekuasaan (Labolo, 2006:34).

Dalam posisi demikian, maka interaksi pemerintahan telah membuat jarak secara diametral posisi yang memerintah dan yang diperintah, termasuk sejumlah konsekuensi yang menyertainya. Keadaan tersebut secara estimologius dfirenkontruksikan oleh Inu Kencan Syafiie berupa empat unsur penting tang terkandung didalamnya, yaitu pemerintah sebagai yang memerintah dan rakyat yang diperintah., kewenangan dan legitimasi yang melekat pada pemerintah, ketaatan pada yang doperintah, serta hubungan timbal balik yang terjadi diantara keduanya, baik secara vertikal maupun horizontal (Syafiie, 2001:115).

B. INTERAKSI HORIZONTAL DALAM PEMERINTAHAN

Kepemimpinan lahir berdasarkan Konsensus yang telah 
disepakati melalui mekanisme pemilkihan oleh elemen lain. Semua interaksi antar elemen berlangsung dengan konstitusi sebagai sentral regulasi (Labolo, 2006:36). Dalam hal ini konstitusi memuat tentang hubungan-hubungan yang bersifat pengaturan termasuk menyangkut reward dan punishment. Interaksi antar elemen juga didasarkan atas chek and balance sistem sehingga kontrol atas jalannya pemerintahan dapat dilakukan secara kolektif. Akuntabilitas antar elemen dapat lebih terjamin disbanding model pertama yang bertumpu pada standar-standar baku dengan interpretasi beberapa orang. Interaksi semacam ini dapat berlangsung lebih stabil apabila semua elemen dapat memainkan fungsi-fungsinya secara maksimal dan proposional. Dengan spesialisasi fungsi sebgau cirri modern dalam pengelolaan pemerintahan, hubungan antar elemen akan saling mendorong dan melengkapi, baik bagi pemegang otoritas tertinggi maupun lembaga-lembaga itu sendiri. Pelayanan difokuskan terhadap kebutuhan sesame elemen, khususnya elemen yang paling membutuhkan, yaitu wilayah (rakyat).

\section{HEGEMONI DALAM PEMERINTAHAN}

Hegemoni dalam pemerintahan adalah pergerakan pemerintah, elemen penting yang paling menunjukan superioritas di antara yang lain akan cenderung melakukan hegemoni untuk menguasai pemerintahan. Mengingat betapa pentingnya keberadaan pemimpin untuk mengelola kolektivitas yang memuat kebutuhan bersama bagi tujuan-tujuan yang diinginkan, maka disengaja atau tidak situasi "primus inter pares" akan sulit terhindarkan dalam masyarakat manapun. Kiranya hal tersebut cukup menjadi salah satu alasan bagi lahirnya pemimpin di antara yang lain. Pola-pola interaksi di antara mereka harus diintegrasikan dan diarahkan sedemikian rupa sehingga tidak terjadi tabrakan kepentingan, di mana antara satu dengan yang lain saling melenbgkapi atau saling melayani guna memenuhi kebutuhan dan menghindari keterbatasan yang dialami 


\section{(Labolo, 2006:36).}

Pada masyarakat tradisional, kecederungan munsulnya hegemoni kekuasaan dalam pemerintahan tidak saja didorong oleh alasan diatas, tetapi lebih dari itu adalah dalam upaya memeprtahankan kepentingan kelompok tertentu.

\section{METODE PENELITIAN}

Metode yang digunakan dalam penelitian ini memakai tipe dan jenis penelitian yakni metode deskriptif kualitatif. Menurut Maleong (2001:3) penelitian deskriptif kualitatif yakni sebagai prosedur penelitian yang menghasilkan data deskriptif berupa kata-kata tertulis atau lisan dari orang-orang dan perilaku yang dapat diamati. Pendekatan kualitatif, peneliti berusaha mengamati dan mengungkap realitas yang terjadi di lapangan kaitan dengan Tata Kelola Kebijakan Qanun Nomor 13 Tahun 2003 tentang maisir (Perjudian) di Kabupaten Gayo Lues, Provinsi Aceh. Jenis penelitian yang digunakan adalah deskriptif, Menurut Sanapiah (1999:20) deskriptif yaitu untuk mengeksplorasi dan mengklarifikasi mengenai suatu fenomena atau kenyataan sosial, dengan jalan mendeskripsikan sejumlah fariabel yang berkenaan dengan masalah atau unit masaalah yang diteliti.

Peneliti memfokuskan lokasi penelitian di lingkungan Dinas Syariat Islam, Mahkamah Syariah serta Satuan Polisi Pamong Praja ( Satpol PP) dan Wilayatul Hisbah (Polisi Syariat Islam) di Kabupaten Gayo Lues Provinsi Aceh. Hal ini dikarenakan Dinas Syariat Islam, Mahkamah Syariah dan Satuan Polisi Pamong Praja dan Wilayatul hisbah (Polisi Syariat Islam) adalah instansi terkait yang memiliki tugas dan tanggung jawab penuh dalam mengurusi tegaknya Syariat Islam.

\section{PEMBAHASAN}

Tata Kelola Kebijakan Qanun Nomor 13 Tahun 2003 Tentang 
Maisir (Perjudian) di Kabupaten Gayo Lues.

\section{A. TUJUAN KEBIJAKAN QANUN NOMOR 13 TAHUN 2003 TENTANG MAISIR (PERJUDIAN).}

Adapun dalam proses perumusan tata kelola kebijakan Qanun nomor 13 tahun 2003 tentang Maisir (perjudian) tujuan kebijakan tersebut adalah untuk untuk memelihara dan melindungi harta benda/kekayaan, mencegah anggota mayarakat melakukan perbuatan yang mengarah kepada maisir, melindungi masyarakat dari pengaruh buruk yang timbul akibat kegiatan dan/atau perbuatan maisir, meningkatkan peran serta masyarakat dalam upaya pencegahan dan pemberantasan perbuatan maisir.

\section{B. KETERLIBATAN MASYARAKAT.}

Jika dilihat keterlibatan masyarakat dalam proses perumusan visi dan misi Kabupaten Gayo Lues lebih kongkritnya dalam Tata Kelola Kebijakan Qanun Nomor 13 Tahun 2003 Tentang Maisir (Perjudian) dirasa masih kurang, hal tersebut terbukti masih banyaknya masyarakat yang belum mengetahui keberadaan Qanun tersebut, berikut hasil wawancara bersama dengan saudara Rudi Mulyadi selaku ketua pemuda Desa Bukit.

"Masih banyak masyarakat yang belum mengetahui tentang qanunqanun yang ada di Kabupaten Gayo Lues, terutama di kalangan pemuda-pemudi yang tidak mengenyam pendidikan di luar daerah, kemudian masyarakat desa juga banyak tidak mengetahui hal tersebut. Ini semua karena masih kurangnya sosialisasi dari pemerintah" ( wawancara dilaksanakan pada hari selasa, 3 desember 2013. Pukul 09.30 Wib di Desa Bukit Kediaman Beliau)

Hal diatas adalah cerminan bahwa dalam proses perumusan kebijakan tersebut masih kurangnya keterlibatan masyarakat, hal tersebut juga senada dengan pernyataan Kapala Dinas Syariat Islam Kabupaten Gayo Lues, Bapak H.Awaluddin,M.S.Ag

"Dalam proses perumusan kebijakan yang berkenaan dengan Syariat 
Islam diakui keterlibatan masyarakat masih kurang berpartisipasi, hal tersebut semata-mata bukan hanya kesalahan pemerintah akan tetapi masyarakat yang di undang sering tidak memenuhi undangan tersebut. Dan yang menjadi prioritas utama segmen masyarakat yang di undang adalah para Imam desa yang mana itu juga hanya berjumlah satu orang per desanya" ( wawancara dilaksanakan pada hari kamis, 7 november 2013. Pukul 08.30 Wib di Ruangan Kepala Dinas Syariat Islam).

Dari hasil wawancara diatas mengindikasikan bahwa dalam proses perumusan Tata Kelola Kebijakan Qanun Nomor 3 Tahun 2003 Tentang Maisir (Perjudian) tersebut masihlah kurang, terutama pernyataan dari Kepala Dinas Syariat Islam H.Awaluddin,M.S.Ag, bahwa yang menjadi prioritas keterlibatan masyarakat baru hanya sebatas Imam desa yang mana jumlah Imam desa per desanya hanya satu. Hal tersebut menunjukan bahwa proses perumusan masih pada tataran hubungan eksekutif dan legislatif belum melibatkan masyarakat secara keseluruhan.

\section{KETERLIBATAN LEMBAGA SWADAYA MASYARAKAT.}

Dalam Tata Kelola Kebijakan Qanun Nomor 13 Tahun 2003 Tentang Maisir (Perjudian ) ini diharapkan pihak diluar pemerintah seperti eksekutif dan legislatif, Lembaga Swadaya Masyarakat diharapkan ikut serta dalam proses perumusan dan implementasinya akan tetapi penelitian melihat bahwa antara pemerintah dan lembaga swadaya masyarakat tidak adanya koordinasi resmi maupun tidak resmi bisa dikatakan tidak adanya sinergisitas antara keduanya, padahal LSM Ilang Using Ijo yang bergerak dibidang Adat bisa diikutsertakan dalam perumusannya sampai pelaksanaan Qanun tersebut, akan tetapi hal tersebut tidak terjadi sama sekali. 


\section{IMPLEMENTASI.}

\section{A. PELAKU KEBIJAKAN}

Dinas Syariat Islam Kabupaten Gayo Lues, merupakan unsur pelaksana pemerintah kabupaten yang dipimpin oleh seorang Kepala Dinas yang berada dibawah dan bertanggungjawab kepada Bupati melalui Sekretaris Daerah Kabupaten.

Mahkamah Syariah adalah lembaga Peradilan Syariat Islam di Nanggroe Aceh Darussalam sebagai pengembangan dari Peradilan Agama yang diresmikan pada tanggal 4 Maret 2003 M atau1 Muharram $1424 \mathrm{H}$ sesuai dengan Undang-undang Nomor 18 Tahun 2001, Keppres Nomor 11 Tahun 2003 dan Qanun Provinsi Nanggroe Aceh Darussalam Nomor 10 Tahun 2002.

Wilayatul Hisbah merupakan satu badan yang berwenang mengontrol/ mengawasi pelaksanaan ketentuan-ketentuan yang diatur dalam peraturan daerah di Aceh sesuai amanat PERDA Nomor 5 Tahun 2000 Wilayatul Hisabah sendiri adalah unit satuan Polisi Pamong Praja Satpol PP (UU Nomor 11/2006 pasal 241 angka (2) yang diberi wewenang khusus dalam menegakkan Syariat Islam.

\section{B. PERUBAHAN YANG DIHARAPKAN.}

Adapun perubahan yang diharapan dengan Qanun nomor 13 tahun 2003 tentang maisir (perjudian) adalah agar tidak terjadi lagi perjudian di tengah-tengah masyaraka. Pada realitas yang mana penulis langsung terjun lansung dilapangan, sebenaranya dapat penulis simpulkan tujuan dari perubahan yang diharapkan dari Qanun Nomor 13 Tahun 2003 Tentang Maisir (Perjudian) belum mengalami perubahan sesuai seperti yang diharapkan, karena masih banyak terjadi pelanggaran yang terjadi seperti judi togel, sabung ayam, judi bola dan lain sebagainya yang bertentangan dengan tujuan dari terbitnya qanun ini. Berikut daftar kita lihat Daftar Pelanggaran Syariat Islam Qanun 13 Tahun 2003 Tentang Maisir (Perjudian) Di Kabupaten Gayo Lues Tahun 2014 
Setelah adanya Qanun ini penulis berpendapat bahwa ada perubahan yang terjadi terhadap pelanggaran judi secara kuantitas di tengah-tengah masyarakat, akan tetapi secara kualitas masih terjadi, maksudnya adalah perjudian masih terjadi ditengah-tengah masyarakat tetapi hanya tempatnya lebih terorganisir dan jauh dari jangkauan masyarakat.

TABEL. 1 PELANGGARAN QANUN NOMOR 13 TAHUN 2003 TENTANG MAISIR (PERJUDIAN) DI KABUPATEN GAYO LUES TAHUN 2014

\begin{tabular}{|c|c|c|c|c|}
\hline №. & $\begin{array}{l}\text { Jenis } \\
\text { Pelanggaran }\end{array}$ & Lokasi & Waktu & Keterangan \\
\hline 1. & Sabung Ayam & Kecamatan Dabungelang & 7 Januari 2014 & Hanya diberi peringatkal \\
\hline 2. & Sabung Ayam & Kecamatan Blangkejeren & 16 Januari 2014 & Tersangka melarikan diri \\
\hline 3. & Judi Togel & Kecamatan Blangkejeren & 12 Februari 2014 & Tersangka melarika diri \\
\hline 4. & Judi Togel & Kecamatan Dabungelang & 23 Maret 2013 & Tersangka Melarikan Dir \\
\hline 5. & Judi Bola & Kecamatan Dabungelang & 14 Mei 2014 & $\begin{array}{l}\text { Hanya dikenakan waïb } \\
\text { lapor } 1 \text { bulan }\end{array}$ \\
\hline 6. & Judi Bola & Kecamatan kota panjang & 18 Mei 2014 & Diberi peringatan \\
\hline 7. & Sabung Ayam & Kecamatan Rikit Gaib & 21 Juni 2014 & Tersangka melarikan diri \\
\hline 8. & Sabung Ayam & Kecamatan Dabunggelang & 29 Juni 2014 & $\begin{array}{l}\text { Hanya disita Ayam dan } \\
\text { tersangka dilepaskan. }\end{array}$ \\
\hline
\end{tabular}

Sumber: Dinas Syariat Islam Kabupaten Gayo Lues

\section{HUBUNGAN PENYELENGGARA QANUN NOMOR 13 TAHUN 2003 TENTANG MAISIR (PERJUDIAN)}

\section{A. HUBUNGAN ANTAR INSTANSI PENYELENGGARA}

Ada beberapa kegiatan yang dilakukan lembaga pelaksana qanun tersebut, dapat dilihat seperti tabel dibawah ini.

Dari tabel diatas dapat dilihat bahwa hanya ada tiga kali hubungan kerja selama tahun 2014 padahal kegiatan disetiap instansi cukup banyak yang berkaitan dengan pelaksanaan Qanun tersebut yang menurut penulis untuk dilaksanakan bersama-sama. Dengan minimnya kerja sama antar lembaga pelaksana Qanun tersebut, menurut penulis adalah salah satu faktor yang menjadikan tujuan dari pelaksanaan Qanun ini tidak berjalan yang baik sesuai dengan harapan. 
TABEL 2. BENTUK HUBUNGAN KERJASAMA ANTAR LEMBAGA PELAKSANAA SYARIAT ISLAM PADA TAHUN 2014

\begin{tabular}{|c|c|c|c|c|}
\hline No & Bentuk Hubungan & Lembaga & Keterangan & Waktu \\
\hline 1. & Swiping bersama & $\begin{array}{l}\text { Dinas Syariat Islam } \\
\text { dengan Satpol PP dan WH }\end{array}$ & $\begin{array}{l}\text { Pada saat swiping Sabung } \\
\text { ayam di Kecamatan } \\
\text { Blangpegayon }\end{array}$ & 7 Januari 2014 \\
\hline 2. & Swiping bersama & $\begin{array}{l}\text { Dinas Syariat Islam } \\
\text { dengan Satpol PP dan WH }\end{array}$ & $\begin{array}{l}\text { Pada saat swiping judi togel } \\
\text { di Kecamatan Blangkejeren }\end{array}$ & 24 agustus 2014 \\
\hline 3. & $\begin{array}{l}\text { Penyuluhan Qanun Ke } \\
\text { Sekolah }\end{array}$ & $\begin{array}{l}\text { Dinas Syariat Islam } \\
\text { dengan Mahkamah } \\
\text { Syariah }\end{array}$ & $\begin{array}{l}\text { Pada saat sosialisasi qanun } \\
\text { syariat islam di SMA N } \\
\text { Seribu Bukit }\end{array}$ & 27 September 2014 \\
\hline
\end{tabular}

B. HUBUNGAN INSTANSI PENYELENGGARA DENGAN MASYARAKAT.

Salah satu cara Pemerintah Kabupaten Gayo Lues untuk mengikutsertakan masyarakat dalam memajukan Syariat Islam di Kabupaten Gayo Lues dengan pembentukan Petugas Pengawas Syariat Islam Kampung(PPSK) memiliki urgensi terhadap penerapan Syariat Islam dari ranah yang paling bahwa yaitu kampung. Petugas Pengawas Syariat Islam kampung (PPSK) Kabupaten Gayo Lues pertama kali dibentuk pada tahun 2009 melalui Surat Keputusan (SK) Bupati Gayo Lues H. Ibnu Hasim Nomor: 451/414/2009 Tanggal 22 juni 2009. Pada saat itu dilantik sebanyak 108 personil Petugas Pengawas Syariat Islam Kampung dengan harapan perjalanan Syariat Islam akan lebih produktif, efektif dan efisien di negeri Seribu Bukit Kabupaten Gayo Lues.

Sebagai pilot proyek (percontohan) PPSK dibentuk di tiga Kecamatan dari sebelas Kecamatan, karena kebijakan ini baru, Kecamatan Ibu kota Kabupaten dan Kecamatan yang terdekat terlebih dahulu dilakukan agar kedepan jika sukses bisa di laksanakan diseluruh Kecamatan. Kecamatan yang ada di Kabupaten Gayo Lues yaitu: Kecamatan Blangkejeren, Kecamatan Dabun Gelang dan Kecamatan Blang Pegayon. Seperti tabel dibawah ini. 


\section{HUBUNGAN INSTANSI PENYELENGGARA DENGAN LEMBAGA SWADAYA MASYARAKAT}

Belum ada satupun instansi penyelenggara Qanun ini yang telah melakukan kerjasama dengan LSM, padahal ada beberapa LSM yang terdaftar di Kantor Kesbangpol dan Linmas Kabupaten Gayo Lues LSM yang bergerak di bidang Adat yang sebenarnya bisa diikutsertakan untuk memberikan masukan dan bersama-sama menjalakan qanun tersebut.

\section{LINGKUNGAN INSTANSI PENYELENGGARA}

\section{A. DUKUNGAN ANGGARAN}

Pada Dinas Syariat Islam terdapat sebelas program atau kegiatan yang dilaksanakan, anggaran kegiatan yang paling besar mendapat anggaran adalah pada program Pengembangan Komunikasi dan Informasi Agama Islam yaitu sebesar Rp. 1.042.270.000,- dan program atau kegiatan yang mendapat anggaran paling kecil adalah pemgembangan nilai Budaya Islami yang bentuk kegiatannya berupa pembuatan billboar/pamphlet asmaul husna sebesar Rp. 50.000.000,-. Dari urutan terbesar dan terkecil tersebut menurut penulis sebenarnya program komunikasi dan informasi agama islam yang mendapat anggaran paling besar dari sebelas program/kegiatan di Dinas Syariat Islam tidak menunjukan kearah penguatan pelaksanaan Syariat Islam itu sendiri karena bentuk kegiatannya menurut penulis kegiatannya yang belum bersentuhan langsung kepada pelaksanaan Syariat Islam itu sendiri. Sedangkan program yang langsung bersentuhan terhadap pelaksanaaan Syariat Islam hanya mendapat anggaran sebesar 305.000 .000 yang mana untuk kegiatan yang berkenaan dengan Qanun Nomor 13 Tahun 2003 ini hanya Rp. 75.000.000,- menurut penulis biaya ini sangatlah kecil dan tidak cukup untuk kegiatan selama setahun. Selain itu juga penulis melihat ada kegiatan dalam pos tersebut masih belum mengakomodir agar pelaksanaa Syariat Islam itu berjalan baik seperti 
penyuluhan pranikah yang mendapat anggaran sebesar Rp.200.000.000,- sedangkan menurut penulis pos kegiatan ini sebenarnya lebih tepat berada pada Kantor Urusan Agama.

Pada kantor satuan polisi Pamong Praja ada enam program kerja dan masing-masing program kerja sudah mempunyai post anggaran, dari keenam program kerja tersebut yang paling besar mendapatkan anggaran pada Program Pelayanan Administrasi Perkantoran sebesar Rp. 480.990.000 yang mana pada program tersebut terdapat item rapat keluar daerah mendapat anggaran sebesar Rp. 185.800.000 sedangkan program kerja yang paling sedikit mendapatkan anggaran adalah Program Pembinaan Pedagang Kaki Lima dan Asongan sebesar Rp. 153.600.000. jika kita lihat program yang berkaitan dengan pelaksanaan Syariat Islam yaitu program peningkatan razia gabungan sangat kecil jika dibandingkan dengan anggaran program kerja yang lainnya yang hanya mendapat anggaran Rp.203.000.000, .Mahkamah Syariah Blangkejeren tahun 2013 mendapat dua DIPA yaitu DIPA Nomor: dipa-005.01.2.401709/2013 5 Desember 2012 dengan nilai Pagu 3.126.540.000,- dan DIPA NO. dipa005.04.2.401710/2012 5 Desember 2012 dengan nilai Pagu 985.000,( Lakip 2014).

\section{B. DUKUNGAN SUMBER DAYA MANUSIA}

Sumber daya manusia merupakan faktor penting dalam menuju misi, tujuan dan pencapaian hasil organisasi. Tanpa adanya sumber daya manusia proses yang ada dalam organisasi tidak dapat dijalankan. Dari berbagai sumber daya yang ada dalam organisasi, manusia merupakan sumber daya yang paling penting dalam organisasi untuk mencapai keberhasilan. Sebab sumber daya manusia merupakan satu-satunya yang punya akal, perasaan keinginan, kemampuan, keterampilan, pengetahuan, dorongan, daya dan karya. (Gomes, 1995: 12).

Penulis melihat dilapangan ada beberapa speksifikasi jurusan 
maupun jenjang pendidikan yang tidak sesua ditempatkan di Dinas Syuariat Islam seperti masih banyaknya Pegawai lulusan SMA/MA setingkat dan sarjan jurusan Pendidikan Bahasa Indonesia dan jurusan Budidaya Daya Tanaman. Ini adalah salah satu tidak maksimalnya instansi pemerintah dalam menjalankan program kegiatannya.

Dari tabel diatas dapat kita lihat sumber daya yang ada bahwa Kantor Polisi Pamong Praja dan Wilayatul Hisbah masih banyak mengunakan tenaga honorer dan pegawai yang lulusan SMA/MA setingkatnya, dan banyak yang pegawai tamatan sarjana yang tidak sesuai dengan dengan Kantor Polisi Pamong Praja dan Wilayatul Hisbah seperti pegawai tamatan teknik dan pendidikan. Seharus di instansi ini menurut penulis harus banyak lulusan kepamongan.

Menurut penulis sumber daya manusia yang ada di Mahkamah Syariah Kabupaten Gayo Lues sudah cukup baik karena presentase antara sarjana dengan buka cukup mencolok dimana pegawai yang sarjana lebih banyak dan sesuai dengan jurusan yang tepat yaitu sarjana ilmu hukum dan dan yang Hukum Islam.

TABEL. 3 . PERINGATAN DPRK GAYO LUES KEPADA LEMBAGA PELAKSANA QANUN NOMOR 3 TAHUN 2003 TENTANG MAISIR (PERJUDIAN)

\begin{tabular}{llll}
\hline No. & Tujuan & Waktu & Perihal \\
\hline 1. & Dinas Syariat Islam & 9 Maret 2014 & Pelaksanaan Syariat Islam Secara Kaffah \\
2. & Satpol PP dan WH & 4 April 2014 & Swiping Rutin \\
3. & Satpol PP dan WH & 8 Juni & Penegakan Hukum Syariat Islam \\
\hline
\end{tabular}

Sumber: Sekretariat DPRK Gayo Lues
WH $\quad$ : Wilayatul Hisbah (Polisi Syariat Islam)

C. DUKUNGAN POLITIK.

Dukungan politik terhadap pelaksanaan Syariat Islam di Kabupaten Gayo Lues sudah diberikan secara baik. Hal tersebut juga terbukti dengan beberapa kali Pimpinan DPRK Gayo Lues melalui Ketua DPRK Gayo Lues memberikan peringatan terhadap 
lembaga pelaksana Syariat Islam. Peringatan yang diberikan DPRK Gayo Lues Kepada Lembaga pelaksana Qanun Nomor 3 Tahun 2003 Tentang Maisir (Perjudian) dapat dilihat pada Tabel 3.

\section{LINGKUNGAN SYARIAT ISLAM}

\section{A. KULTUR MASYARAKAT}

Budaya masyarakat yang bernafaskan Islam belum berpengaruh secara aktif dalam pelaksanaa Qanun Nomor 3 Tahun 2003 Tentang Maisir (Perjudian) ini di lapangan terbukti dengan masih adanya pelanggaran yang dilakukan masyarakat. Hal tersebut menurut penulis kehadiran lembaga-lembaga pelaksana Syariat Islam seperti Dinas Syariat Islam, Satuan Polisi dan Wilayatul Hisbah, Mahkamah Syariah serta PPSK di tengah-tengah masyarakat belum diterima secara penuh karena kurangnya sosialisasi dari lembaga-lembaga tersebut akan peran masyarakat dalam pelaksanaan Qanun ini, seakan-akan dengan adanya lembaga ini masyarakat seperti lepas tangan, masyarakat mengggap bahwa lembaga ini adalah aktor tunggal yang berperan dalam pelaksanaan Syariat Islam. Berikut adalah daftar pelanggaran Qanun Nomor 3 Tahun 2003 Tentang Maisir (Perjudian) di Kabupaten Gayo Lues.

\section{TABEL. 4. DAFTAR PELANGGARAN QANUN NOMOR 13 TAHUN 2003 TENTANG MAISIR (PERJUDIAN) DI KABUPATEN GAYO LUES TAHUN 2014}

\begin{tabular}{clll}
\hline No. & Jenis Pelanggaran & Lokasi & Waktu \\
\hline 1. & Sabung Ayam & Kecamatan Dabungelang & 7 Januari 2014 \\
2. & Sabung Ayam & Kecamatan Blangkejeren & 16 Januari 2014 \\
3. & Judi Togel & Kecamatan Blangkejeren & 12 Februari 2014 \\
4. & Judi Togel & Kecamatan Dabungelang & 23 Maret 2013 \\
5. & Judi Bola & Kecamatan Dabungelang & 14 Mei 2014 \\
6. & Judi Bola & Kecamatan Kota paniang & 18 Mei 2014 \\
7. & Sabung Ayam & Kecamatan Rikit Gaib & 21 Juni 2014 \\
8. & Sabung Ayam & Kecamatan Dabunggelang & 29 Juni 2014 \\
\hline
\end{tabular}




\section{B..KULTUR PEMERINTAH}

Kultur Pemerintah pada tataran pelaksanan Qanun Nomor 3 Tahun 2003 Tentang Maisir (Perjudian) di Kabupaten Gayo Lues khususnya pada proses hukuman yang diberikan pada pelanggar masih jauh dari harapan, hal itu terbukti dari kasus pelanggaran yang dilakukan masyarakat belum ada satupun hukum yang sesuai dengan Qanun Nomor 3 Tahun 2003 dimana jika ada yang melanggar akan diancam ('Uqubat) cambuk sebanyak 12 (dua belas) kali dan paling sedikit 6 (enam) kali di depan umum. Berikut adalah pelanggaran Qanun Nomor 3 Tahun 2003 Tentang Maisir (Perjudian) di Kabupaten Gayo Lues Tahun 2014:

Tabel..5. Daftar Pelanggaran Qanun Nomor 13 Tahun 2003 Tentang Maisir (Perjudian) dan Hukumannya di Kabupaten Gayo Lues Tahun 2014

\section{KESIMPULAN}

Berdasarkan pembahasan dan hasil penelitian yang telah diuraikan pada Bab-bab sebelumnya, maka dapatlah di tarik kesimpulan terkait dengan Tata Kelola Kebijakan Qanun Nomor 13 Tahun 2003 tentang maisir ( Perjudian) di Kabupaten Gayo Lues Provinsi Aceh adalah sebagai berikut:

1. Tata Kelola Kebijakan Qanun Nomor 13 Tahun 2003 tentang maisir ( Perjudian) di Kabupaten Gayo Lues belum berjalan dengan baik, karena dalam proses pelaksanaan kebijakan Qanun tersebut dilapangan belum adanya interaksi yang melibatkan masyarakat secara utuh, begitu juga halnya belum adanya hubungan atau interaksi sama sekali yang dibangun dari Instansi Pelaksana Syariat Islam khususnya Qanun Nomor 13 Tahun 2003 tentang maisir (Perjudian) dengan Lembaga Swadaya Masyarakat (LSM).

2. Upaya yang dilakukan Pemerintah Kabupaten Gayo Lues untuk mengikut adilkan masyarakat dengan cara membuat Pengawas 
Pelaksana Syariat Islam Kampung (PPSK) yang dikoordinatori oleh Camat masing-masing, yang mana itu juga hanya tiga kecamatan yang dibentuk dari sebelas jumlah kecamatan di Kabupaten Gayo Lues. Masyarakat justru tidak mengetehui keberadaan dari PPSK tersebut dan pihak kecamatan juga mengakui bahwa PPSK tidak berjalan karena tidak adanya tindak lanjut untuk menjalankan fungsi dari PPSK tersebut. Sehingga pelaksanaan Qanun Nomor 13 Tahun 2003 tentang maisir ( Perjudian) ini belum memberikan perubahan secara signifikan dengan bukti masih terjadinya perjudian di tengah-tengah masyarakat seperti sabung ayam dan judi togel.

3. Hubungan antar lembaga pelaksana Kebijakan Qanun Nomor 13 Tahun 2003 tentang maisir ( Perjudian) di Kabupaten Gayo Lues. Lembaga pelaksana kebijakan Qanun Nomor 13 Tahun 2003 tentang maisir ( Perjudian) di Kabupaten Gayo Lues terdiri dari tiga lembaga yaitu Dinas Syariat Islam, Satuan Polisi Pamong Praja dan Wilayatul Hisbah serta Mahkamah Syariah, dalam pelaksanaan Qanun ini masing-masing mempunyai peran dan fungsi masing-masing sehingga ketiga lembaga ini adalah satu kesatuan yang utuh dalam pelaksanaanya, namun dilapangan hubungan yang antar ketiga lembaga ini belum ada satu peraturan, Qanun Kabupaten, maupun MOU yang mengatur hubungan kerja mereka untuk melaksanakan peran dan fungsinya, ketiga lembaga ini seperti berjalan sendiri-sendiri tanpa adanya koordinasi.

4. Nilai keislaman sudah membudaya ditengah-tengah masyarakat Kabupaten Gayo Lues dengan hukum adatnya di setiap kampung, aktivitas kemasyarakatan beracuan kepada hukum adat dikampung tersebut, dengan adanya lembaga Dinas Syariat Islam, Satuan Polisi Pamong Praja Dan Wilayatul Hisbah Serta Mahkamah Syariah kemudian pembentukan PPSK seakan-akan 
570 menghilangkan peran hukum adat itu sendiri sehingga masyarakat seperti lepas tangan terhadap hukum adat yang ada selama ini ditengah-tengah masyarakat.

Sementara itu, Saran nya sebagai berikut:

1. Agar Tata Kelola Kebijakan Qanun Nomor 13 Tahun 2003 tentang maisir ( Perjudian) di Kabupaten Gayo Lues berjalan dengan baik, agar kiranya Pemerintah Kabupaten Gayo Lues dalam hal ini Dinas Syariat Islam, Kantor Satuan Polisi Pamong Praja dan Wilayatul Hisbah serta Mahkamah Syariah untuk mengikutsertakan masyarakat secara aktif mulai dari perencanaan sampai dengan pelaksannaan Syariat Islam khususnya pelaksanaan Qanun Nomor 13 Tahun 2003 tentang maisir ( Perjudian), serta juga mengikutsertakan Lembaga Swadaya Masyarakat secara aktif disegala bentuk prosesnya.

2. Agar upaya yang dilakukan Pemerintah Kabupaten Gayo Lues untuk mengikutsertakan masyarakat dalam pelaksanan Syariat Islam berjalan dengan baik penulis menyarankan, agar Pengawas Pelaksana Syariat Islam Kampung (PPSK) yang dikoordinatori oleh Camat masing-masing bisa di aktifkan sesuai dengan peran dan fungsinya sesungguhnya. Dan agar Pemerintah Daerah Gayo Lues dalam hal ini Bupati Gayo Lues membentuk PPSK diseluruh Kecamatan yang berjumlah sebelas Kecamatan dan menerbitkan Surat Instruksi Bupati tentang Tindak Lanjut Surat Keputusan Nomor: 451/414/2009 Tanggal 22 juni 2009 tentang pembentukan PPSK.

3. Agar Lembaga Pelaksana Kebijakan Qanun Nomor 13 Tahun 2003 tentang Maisir (Perjudian) di Kabupaten Gayo Lues yang terdiri dari Dinas Syariat Islam, Satuan Polisi Pamong Praja dan Wilayatul Hisbah serta Mahkamah Syariah menjalin komunikasi agar ada hubungan yang baik. Penulis menyararankan agar Hubungan antar lembaga tersebut bisa di tetapkan melalui 
Peraturan Bupati atau MOU antar ketiga lembaga tersebut disertai dengan butir-butir kesepakatan kemudian diketahui oleh Bupati Gayo Lues.

4. Agar Dinas Syariat Islam, Kantor Polisi Pamong Praja dan Wilayatul Hisbah serta Mahkamah Syariah mensosialisasikan peran dan fungsinya kepada Masyarakat agar masyarakat paham ranah kerja ketiga lembaga tersebut, kemudian terkait PPSK juga Pemerintah Daerah melalui Bagian Tata Pemerintahan menjelaskan peran masyarakat dalam PPSK tersebut agar masyarakat mengetahui secara jelas dimana perannya dalam pelaksanaan Syariat Islam khususnya pelaksanaan Kebijakan Qanun Nomor 13 Tahun 2003 tentang Maisir ( Perjudian) di Kabupaten Gayo Lues.

\section{DAFTAR PUSTAKA}

BUKU

Abdul, Wahab, Solichin. 1990. Pengantar Analisis Kebijkan Negara. Jakarta: Rineka.

Abdul, Wahab, Solichin. 2002. Analisis Kebijakan: Dari Formulasi Implementasi Kebijakan Negara. Jakarta: Sinar Grafika.

Abdul, Abdul, Wahab. 2008. Analisi Kebijaksanaan Dari Formulasi Ke Implementasi Kebijaksanaan Negara. -Ed.2,Cet.6. Jakarta: Bumi Aksara.

Abdul Wahab, Solichin. 2012. Analisis Kebijakan Dari Formulasi Ke Penyusunan ModelModel Implementasi Kebijakan Publik. Jakarta: Bumi Aksara.

Ali, Muhammad Daud. 2012. Hukum Islam: Pengantar IImu Hukum dan Tata Hukum Islam di Indonesia. Jakarta: Rajawali Pers.

Akmal, Imelda. 2005. Mekanisme, persyaratan, dan tata cara Pilkada langsung menurut undang-undang. Jakarta: Gramedia

Ash-Shadr, Syaid Muhammad Bagir. 2001. Sistem Politik Islam. Jakarta: Letera

Bajuri, Abdul Kahar dan Teguh Yuwono. 2002. Kebijakan Publik konsep dan strategi JLP UNDIP Semarang.

Bogdan Robert C and Sari Knopp Biklen. 1982. Qualitative Research for education: an. Introduction to Theory and Methods. Boston: Alin and Bacon.

Bungin Burhan. 2012. Metodologi Penelitian Kualitatif, (aktualisas, Metodogis kearah ragam varian kontemporer. Jakarta: Rajawali pers.

Dunn, William, N. 1999. Pengantar Analisis Kebijakan Publik. -Ed.2, Cet.2. Yogyakarta: Gadjah Mada University Press.

Hadi, Amirul. 2010. Aceh: Sejarah, Budaya dan Tradisi. Jakarta: Buku Obor 
Indiahono, Dwiyanto. 2009. Kebijakan Publik Berbasis Dynamic Policy Analysis. Yogyakarta: Gava Medi.

Islamy, Irfan. 2009. Prinsip-prinsip Perumusan Kebijakan Negara. Jakarta: Bumi Aksara Islamy, M.I. 2002. Prinsip-prinsip Perumusan Kebijakan Negara. -Ed.2, Cet.11, Jakarta: Bumi Aksara.

Islamy, M.I. 2009. Prinsip-Prinsip Perumusan Kebijakan Negara, -Ed.2, Cet.15, Jakarta: Bumi Aksara.

Lincoln, Yvona S, dan Egon G, Guba. 1985. Naturalistic Inquiry, Beverly Hills: Sage Publications.

Moleong J. Lexy. 2001. Metode Penelitian Kualitatif, -Cet.1, Bandung: Remaja Rosda Karya.

Noor, Juliansyah. 2011. Metodologi Penelitian: Skripsi, Tesisi, desertasi, dan Karya Ilmiah. Jakarta: kencana.

Zuriah, Nurul. 2007. Metodologi Penelitian Sosial Dan Pendidikan Teori dan Praktik.

Parsons, Wayne. 2011. Publik Policy:Pengantar Teori dan Praktik Analisis Kebijakan. Ed.1, Cet.4. Jakarta: Kencana.

Ripley, Randall B. 1986. Policy Analysis In Political Science, Nelson Hall Publisher, chichago.

Hogwood, Brian W., and Lewis A. Gunn. Policy Analysis For The Real World. Oxvord University Press.

Sanapiah, Faisal. 1999. Format-Format Penelitian Sosial, Jakarta, Gramedia.

Santosa, Pandji. 2008. Administrasi Publik: Teori dan Aplikasi Good Governace.-Cet.1. Bandung: Refika Aditama.

Santosa, Pandji. 2009. Administrasi Publik:Teori dan Aplikasi Good Governace. -Cet.2, Bandung: Refika Aditama.

Sugiyono. 2010. Metode Penelitian Kualitatif R \& D, Bandung: Alfabeta.

Suryabrata, Sumadi. 1983. Metode Penelitian. Jakarta: Raja Grafindo Persada.

Syakrani dan Syahriani. 2009. Implementasi Otonomi Daerah Dalam Perspektif Good Governace. Yogyakarta: Pustaka Pelajar.

Thoha, Miftah. 2003. Birokrasi dan Politik di Indonesia, Jakarta, PT Raja Grafindo Persada.

JURNAL

Baun Thaib. 2013. "Neoliberalisasi Pendidikan Islami Di Aceh: Analisis Kritis Terhadap

Qanun Aceh Nomor 5 Tahun 2008". Jurnal IImiah DIDAKTIKA, 14 (1), 1-23.

Djojosoekarto, Agung. 2008. "Kebijakan Otonomi Khusus". Kemitraan Partnership.

Hasani, Ismail. 2007. "Panduan Pemantauan Kebijakan Daerah dengan perspektif HAM dan Keadilan Gender berangkat dari pengalaman Aceh". Publikasi Komnas Perempuan Maret 2007.

Triastuti, Maria Rosarie Harni. 2003. "Rekonsiliasi Nilai Demokrasi dan Birokrasi dalam Proses Formulasi Kebijakan Publik". JAP, Nomor 2 Volume 2003 Oktober 2003. 